\title{
Economic analysis of an agrosilvipastoral system for a mountainous area in Zona da Mata Mineira, Brazil
}

\author{
Marcelo Dias Müller(1), Gilciano Saraiva Nogueira ${ }^{(2)}$, Carlos Renato Tavares de Castro(1), \\ Domingos Sávio Campos Paciullo(1), Frederico de Freitas Alves ${ }^{(3)}$, Renato Vinícius Oliveira Castro ${ }^{(3)}$ \\ and Elizabeth Nogueira Fernandes ${ }^{(1)}$
}

\begin{abstract}
(1)Embrapa Gado de Leite, Rua Eugênio do Nascimento, oo610, Dom Bosco, CEP 36038-330 Juiz de Fora, MG, Brazil. E-mail: muller@cnpgl.embrapa.br, castro@cnpgl.embrapa.br, domingos@cnpgl.embrapa.br, nogueira@cnpgl.embrapa.br (2)Universidade Federal dos Vales do Jequitinhonha e Mucuri, Rua Glória, oo 187, Centro, CEP 39100-000 Diamantina, MG, Brazil. E-mail: nogueirags@yahoo.com.br ${ }^{(3)}$ Universidade Federal de Viçosa, Avenida Peter Henry Rolfs, s/no , Campus Universitário, CEP $36570-000$ Viçosa, MG, Brazil. E-mail: fredufv@hotmail.com, castrorvo@ymail.com
\end{abstract}

\begin{abstract}
The objective of this work was to evaluate the economic viability of an agrosilvipastoral system developed for Zona da Mata mountainous areas in Minas Gerais state, Brazil, as well as to compare different options for wood (Eucalyptus grandis and Acacia mangium) commercialization of the second thinning. The data were obtained from a 10 year-old agrosilvipastoral system established in four hectares at Embrapa Gado de Leite station in Coronel Pacheco, MG, Brazil. As evaluation criteria for the economic viability analysis, the adopted methods were the net present value (NPV) and the internal rate of return (IRR), both calculated at $6 \%$ interest rate. Despite the small difference, adding value to forest products increased the attractiveness of the proposed system. Considered separately, the agricultural activity was impracticable, whereas the forestry and livestock activities were independently viable. The studied system seems to be equally tolerant to price variations for forest and livestock products, as well as strongly tolerant to variations in production costs.
\end{abstract}

Index terms: Acacia mangium, Eucalyptus grandis, alternative land use, rural development, wood multiproducts.

\section{Análise econômica de um sistema agrossilvipastoril de área montanhosa na Zona da Mata mineira}

Resumo - O objetivo deste trabalho foi avaliar a viabilidade econômica de um sistema agrossilvipastoril, desenvolvido para áreas montanhosas da Zona da Mata mineira, Brasil, bem como comparar diferentes alternativas de comercialização da madeira (Eucalyptus grandis and Acacia mangium) do segundo desbaste. Os dados foram obtidos em um sistema agrossilvipastoril com dez anos de idade, implantado em área de quatro hectares, no Campo Experimental de Coronel Pacheco, pertencente à Embrapa Gado de Leite. Como critérios de avaliação para a análise de viabilidade econômica, foram utilizados os métodos do valor presente líquido e o da taxa interna de retorno, ambos calculados para a taxa de juros de $6 \%$. Apesar da pouca diferença, a agregação de valor ao produto florestal aumentou a atratividade do sistema. Considerada isoladamente, a atividade agrícola se mostrou inviável, enquanto a silvicultura e a atividade pecuária foram independentemente viáveis. O sistema estudado parece ser igualmente tolerante a variações nos preços do produto florestal e do produto pecuário, assim como fortemente tolerante a variações nos custos de produção.

Termos para indexação: Acacia mangium, Eucalyptus grandis, uso alternativo da terra, desenvolvimento rural, multiprodutos da madeira.

\section{Introduction}

Agrosilvipastoral systems are characterized by the integration of trees, pasture and grazing animals occurring simultaneously or at different stages. These systems represent a type of land use in which forestry and livestock activities are combined to generate complementary production through the interaction of their components. They are a valuable alternative for sustainable land use because they ensure: protection against erosive agents, water conservation and re-supply of underground waters, maintenance of the hydrological cycle and improvement of soil physical and chemical properties (Macedo, 2000; Xavier et al., 2003; Castro et al., 2009), the improvement of forage quality (Castro et al., 1999; Paciullo et al., 2007) and

Pesq. agropec. bras., Brasília, v.46, n.10, p.1148-1153, out. 2011 
animal thermal comfort (Paes Leme et al., 2005); a better performance of grazing bovines (Paciullo et al., 2009); and socioeconomic benefits such as product diversification, job and income generation as well as reduction of seasonal demand for field labor (Macedo, 2000), which makes the regional livestock activity more sustainable and profitable (Franco, 2000). Coelho Júnior et al. (2008) reported that agrosilvipastoral systems constitute a promising alternative to minimize the risks of forest-related investments, besides being of low risk.

Besides the agricultural and livestock products obtained during the exploitation of an agrosilvipastoral system, the commercialization of forest products obtained at the end of the cycle significantly increase income. According to Souza et al. (2007), adding value to forest products is very likely to increase the system viability and profitability. Consequently, considering the long-term capital assets, all pasture management should ensure the production of different wood products, optimizing their use according to the market potential.

Therefore, Embrapa Gado de Leite has developed an agrosilvipastoral system for mountainous regions aimed at associating conservationist and economic aspects (Carvalho et al., 2002). However, the literature on the economic assessment of these systems is scarce.

The objective of this study was to assess the economic viability of an agrosilvipastoral system designed for mountainous areas of Zona da Mata, in Minas Gerais state, Brazil, as well as to compare different options for wood commercialization of the second thinning.

\section{Materials and Methods}

The data assessed in the present study were obtained from a 10-year-old mixed agrosilvipastoral system, established in a 4-ha area, at Embrapa Gado de Leite station, in Coronel Pacheco county, $\left(21^{\circ} 33^{\prime} \mathrm{S}, 43^{\circ} 06^{\prime} \mathrm{W}\right.$, altitude of $410 \mathrm{~m})$ in a mountainous area with an oxisol of low natural fertility, located in Zona da Mata, Mina Gerais, Brazil.

The climate in the region, according to Köppen, is classified as Cwa, mesothermal, with hot and rainy summers and cold and dry winters. The average annual rainfall is over $1,500 \mathrm{~mm}$, unevenly distributed, with only $13 \%$ occurring from May to September, which is considered the dry season. The average temperature is $18^{\circ} \mathrm{C}$ in the winter and $22^{\circ} \mathrm{C}$ in the summer.

The chemical properties of the soil, before planting, were: water $\mathrm{pH}, 4.61$; available $\mathrm{P}$ (Melhich)
$4.47 \mathrm{mg} \mathrm{dm}{ }^{-3} ; \mathrm{K}, 0.11 \mathrm{cmol}_{\mathrm{c}} \mathrm{dm}^{-3} ; \mathrm{Ca}, 0.33 \mathrm{cmol}_{\mathrm{c}} \mathrm{dm}^{-3}$; $\mathrm{Mg}, 0.12 \mathrm{cmol}_{\mathrm{c}} \mathrm{dm}^{-3} ; \mathrm{Al}, 0.79 \mathrm{cmol}_{\mathrm{c}} \mathrm{dm}^{-3}$.

Trees were arranged in 10-m wide strips of land, in contour lines, intercalated with $30-\mathrm{m}$ wide strips used for grazing. The system was composed of two tree species, Eucalyptus grandis W. Mill ex Maiden and Acacia mangium Willd., and two grass species, Urochloa decumbens (Stapf) R.D. Webster and Stylosanthes guianensis (Aubl.) Sw var. vulgaris cv. Mineirão.

The system was established as follows: the trees were planted in rows (within $3 \times 3 \mathrm{~m}$ initial spacing) and pigeon peas (Cajanus cajan (L.) Huth) were planted in the treeless strips (30-m wide). The grazing area was established in the second year with corn. The rows were established at 1-m intervals, with seed density of $20 \mathrm{~kg} \mathrm{ha}^{-1}$. Before planting, furrows with $2,000 \mathrm{~kg} \mathrm{ha}^{-1}$ of dolomitic limestone and $150 \mathrm{~kg} \mathrm{ha}^{-1}$ of 8-28-16 + 0.5\% Zn commercial formulation were made. The trees were not protected by fences, and the grazing season started 22 months after tree planting, when the trees were 5-m high in average, and could not be reached by the animals.

When the trees were seven years old, a selective thinning of eucalyptus was done, in order to increase the photosynthetically active radiation and the fertilization efficiency in the test area, and to reduce the time required for producing large trees with better wood quality to obtain forest products which could yield intermediate inputs, before the final cut.

The experimental area was divided into eight plots which were managed in a rotational stocking system, with seven days of grazing and 35 and 49 days of rest in the rainy and dry seasons, respectively. The animals used were Holstein x Zebu heifers, with $250 \mathrm{~kg}$ initial live body weight. The average number of heifers per hectare varied between 1.48 and 2.53 , corresponding to stocking rates between 0.8 and $1.6 \mathrm{AU} \mathrm{ha}^{-1}$, in the dry and rainy seasons, respectively. The heifers were replaced every year with others with similar initial live weight.

In 2007, the diameter at breast height (DBH) of 239 eucalyptus and 177 acacia trees was measured. The total height was also estimated, and a strict scale of 27 eucalyptus and 17 acacia trees was done using a Weller pentaprism (Forestry Suppliers; Jackson, MS, USA) and a Suunto optical clinometer (Suunto, Helsink, Finland). The total heights of eucalyptus trees $(\mathrm{H})$ that were not estimated in the field were assessed by means of hypsometric equations. Taper models that permit the estimation of the diameter (d) at any given point, the height where a given diameter occurs and 
the volume of parts of the trunk were used to quantify wood multiproducts.

The selection of hypsometric volumes and taper was based on the adjusted determination coefficient $\left(\overline{\mathrm{R}}^{2}\right)$, on the standard error of residuals $\left(\mathrm{S}_{\mathrm{yx}}\right)$, on the correlation coefficient (R) and on graphical analysis of residuals. The selected hypsometric equation was:

$\mathrm{LnH}=3.598702+11.624611(1 / \mathrm{dbh}), \overline{\mathrm{R}}^{2}=0.94 ; \mathrm{S}_{\mathrm{yx}}=0.087$.

Demaerschalk's taper model (Demaerschalk, 1972) was selected. The equations for eucalyptus and acacia are the following:

eucalyptus: $(\mathrm{d} / \mathrm{dbh})^{2}=10^{2(0.171662)} \mathrm{dbh}^{2(0.913752)-2} \mathrm{H}^{2(-1.66564)}$ $(\mathrm{H}-\mathrm{h})^{2(1.659757)}, \mathrm{R}^{2}=0.95$.

acacia: $(\mathrm{d} / \mathrm{dbh})^{2}=10^{2(0.332365)} \mathrm{dbh}^{2(0.956373)-2} \mathrm{H}^{2(-1.972441)}$ $(\mathrm{H}-\mathrm{h})^{2(1.806352)}, \mathrm{R}^{2}=0.94$.

After the calculation of hypsometric equations and taper, the product characteristics (length of logs, maximum and minimum diameter), the net revenue and feasible alternatives were simulated in alternative settings for wood conversion into multiproducts from the combination of the different uses. A computer application for multiproduct optimization, based on a dynamic programming model developed by Leite et al. (1995), was used for these simulations. This application makes it possible to assess the best use (including sawn timber) of every segment of the tree.

Three wood use alternatives were assessed considering the potential market of the region: as energy sources (charcoal and firewood), fencing stakes and sawn timber. The wood multiproduct specifications adopted - minimum and maximum diameters, and length were, respectively: for sawn timber, 20, 200 and $300 \mathrm{~cm}$; for charcoal, 4, 25 and $200 \mathrm{~cm}$; and for fencing stakes, 9,25 and $200 \mathrm{~cm}$.

Implementation, maintenance harvesting and transport costs for 10 years were considered. The revenue yield of every commercialized product and that resulting from the sale of standing timber were considered. Furthermore, the implementation, maintenance and harvesting costs of corn and the costs of acquisition of calving cows and their re-breeding management were also considered (Table 1).

The revenue structure was composed of the forest production of fencing stakes, posts and firewood after seven years, and of the estimates of the volume of wood for energy purposes, fencing stakes, volume of sawn timber at ten years, besides animal production represented by the gain of live weight during the system implementation/execution stages and of the corn yield in the second year (Table 2).

The net present value (NPV) and internal rate of return (IRR) criteria were used in the economic evaluation. A 10 -year period and an interest rate of $6 \%$ were considered.

In order to evaluate the revenue yield from timber sales, the following alternatives were considered: standing timber sale; roadside sale of timber; and sale of timber delivered to the customer.

Three theoretical scenarios were simulated to determine the sensitivity of the economic criteria used to evaluate variations in the product (from livestock, forest and agriculture) prices, in production costs, yields and discount rates, in order to establish the

Table 1. Cost structure per hectare.

\begin{tabular}{lcc}
\hline Item & Year & Value (US\$) \\
\hline Soil preparation & 0 & 165.63 \\
Tree planting & 0 & 193.00 \\
Maintenance of trees for the first year & 0 & 54.07 \\
Maintenance of trees & $1-10$ & 25.00 \\
Pasture establishment & 1 & 219.90 \\
Installation of fixed fences & 1 & 770.00 \\
Planting of pigeon peas & 0 & 277.50 \\
Clearing of land and inclusion of pigeon peas & 0 & 106.25 \\
Corn planting & 1 & 668.59 \\
Corn harvest & 1 & 86.68 \\
Maintenance of fences & $2-10$ & 35.15 \\
Livestock inputs & $2-10$ & 46.00 \\
Timber harvesting $\left(\mathrm{US} \$ \mathrm{~m}^{-3}\right)^{(1)}$ & 7 and 10 & 5.77 \\
Timber transport $\left(\mathrm{US} \$ \mathrm{~m}^{-3}\right)^{(1)}$ & 10 & 5.13 \\
\hline
\end{tabular}

${ }^{(1)}$ Source: Souza et al. (2007).

Table 2. Revenue structure per hectare.

\begin{tabular}{|c|c|c|c|c|}
\hline Agrosilvipastoral product & Year & Amount & $\begin{array}{c}\text { Unit price } \\
\text { (US\$) }\end{array}$ & $\begin{array}{c}\text { Revenue } \\
\text { (US\$) }\end{array}$ \\
\hline Firewood (st) - real value & 7 & 20 & 12.50 & 250.00 \\
\hline Fencing stakes (unit) & 7 & 100 & 3.75 & 375.00 \\
\hline Posts (unit) & 7 & 3 & 82.50 & 247.50 \\
\hline Standing timber $\left(\mathrm{m}^{3}\right)$ & 10 & 40 & 20.00 & 800.00 \\
\hline Sawn timber $\left(\mathrm{m}^{3}\right)^{(1)}$ & 10 & 15.9 & 40.00 & 636.00 \\
\hline Sawn timber $\left(\mathrm{m}^{3}\right)^{(2)}$ & 10 & 15.9 & 60.00 & 954.00 \\
\hline Firewood $\left(\mathrm{m}^{3}\right)^{(1)}$ & 10 & 6.4 & 17.50 & 112.00 \\
\hline Firewood $\left(\mathrm{m}^{3}\right)^{(2)}$ & 10 & 6.4 & 22.50 & 144.00 \\
\hline Fencing stakes (unit) & 10 & 140 & 3.75 & 525.00 \\
\hline Meat production (kg) & $2-10$ & 305 & 1.15 & 350.75 \\
\hline $\operatorname{Corn}(\mathrm{kg})^{(3)}$ & 2 & $4,000^{(4)}$ & 0.19 & 740.00 \\
\hline
\end{tabular}


influence of these factors on the economic viability of the system. Besides the $6 \%$ discount rate, 8, 10 and $12 \%$ rates were simulated.

\section{Results and Discussion}

At a $6 \%$ discount rate, both NPV and IRR indicate that all the alternatives for yield revenue from timber sales were feasible (Table 3 ). These values have also shown that the added value of forest-based products (alternative 3), with all the other products remaining constant, increased attractiveness. Souza et al. (2007) obtained similar results in their study of an agroforestry

Table 3. The net present value (NPV) and the internal rate of return (IRR) of the system, considering the three alternatives (1, sale of standing timber; 2 , sale of roadside timber; and 3 , sale of timber delivered to the customer), for yield revenue from timber sales at a $6 \%$ discount rate and considering the isolated components (plantation, livestock and silviculture) at the same discount rate.

\begin{tabular}{lcccccc}
\hline \multirow{2}{*}{$\begin{array}{l}\text { Evaluation } \\
\text { criteria }\end{array}$} & \multicolumn{3}{c}{ Alternative } & \multicolumn{3}{c}{ Plantation Livestock Silviculture } \\
\cline { 2 - 4 } & 1 & 2 & 3 & & & \\
\hline NPV (US\$) & 576.12 & 740.00 & 871.66 & -90.31 & 828.50 & 585.18 \\
IRR (\%) & 10.00 & 11.00 & 11.65 & - & 19.00 & 17.00 \\
\hline
\end{tabular}

${ }^{(1)}$ Considering alternative 3 . system in northwestern Minas Gerais, Brazil. Dube et al. (2002) studied a eucalypt-based agroforestry system, in the Cerrado region of Brazil, and showed that if more wood could be sawn, better returns could be obtained.

Separate analysis of the system's components (plantation, livestock and silviculture) showed that corn was not economically viable on its own, while livestock and silviculture were individually viable (Table 3 ). Thus, these activities have a greater impact on the system's viability. However, it is essential to evaluate the system viability as a whole because all the other benefits provided by trees in grazing areas (as organic matter introduction and nitrogen fixation - due to presence of legume trees) favor the production and quality of forage matter; besides, tree shadow increases thermal comfort and consequently animal production should be considered (Paes Leme et al., 2005; Paciullo et al., 2009). The results of the present study are consistent with those obtained by Souza et al. (2007), who concluded that the system viability was strongly dependent on forestry and livestock activities. It is important to emphasize that the system showed positive cash flow starting from the second year due to revenues from corn and weight gain of the animals, in the three situations (Table 4).

Table 4. Cash flow for the three alternatives: 1 , sale of standing timber; 2 , sale of roadside timber; and 3, sale of timber delivered to the customer.

\begin{tabular}{|c|c|c|c|c|}
\hline Initial investment & Year & Alternative 1 (US\$) & Alternative 2 (US\$) & Alternative 3 (US\$) \\
\hline Pasture establishment & 0 & 385.53 & 385.53 & 385.53 \\
\hline Tree planting & 0 & 247.07 & 247.07 & 247.07 \\
\hline Fencing installation & 0 & 770.00 & 770.00 & 770.00 \\
\hline Pigeon peas planting/introduction & 0 & 383.75 & 383.75 & 383.75 \\
\hline Corn planting/harvest & 0 & 755.27 & 755.27 & 755.27 \\
\hline 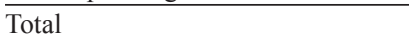 & & $2,541.61$ & $2,541.61$ & $2,541.61$ \\
\hline \multicolumn{5}{|l|}{ Cash inflow } \\
\hline Corn & 1 & 740.00 & 740.00 & 740.00 \\
\hline Meat & $1-10$ & 350.75 & 350.75 & 350.75 \\
\hline Firewood & 7 & 250.00 & 250.00 & 250.00 \\
\hline Fencing stakes & 7 & 375.00 & 375.00 & 375.00 \\
\hline Posts & 7 & 247.50 & 247.50 & 247.50 \\
\hline Fencing stakes & 10 & 0.00 & 526.50 & 526.50 \\
\hline Standing timber & 10 & 800.00 & 0.00 & 0.00 \\
\hline Sawn timber & 10 & 0.00 & 637.50 & 954.00 \\
\hline Charcoal & 10 & 0.00 & 111.25 & 144.00 \\
\hline Total & - & $2,763.25$ & $3,238.50$ & $3,587.75$ \\
\hline \multicolumn{5}{|l|}{ Cash outflow } \\
\hline Tree maintenance & $1-10$ & 25.00 & 25.00 & 25.00 \\
\hline Fence maintenance & $1-10$ & 35.15 & 35.15 & 35.15 \\
\hline Livestock inputs & $1-10$ & 46.00 & 46.00 & 46.00 \\
\hline Timber harvesting & 7 & 115.40 & 115.40 & 115.40 \\
\hline Transport & 10 & 0.00 & 0.00 & 114.30 \\
\hline Timber harvesting & 10 & 0.00 & 179.45 & 179.45 \\
\hline Total & - & 221.55 & 401.00 & 515.30 \\
\hline
\end{tabular}


For the variation in the product prices, three alternatives were considered because although the sale of timber delivered to the customer is the most economically attractive, it is the least frequent according to a study by Fontes et al. (2003).

The simulations of price variations of agroforestry products showed that to achieve a cost/revenue balance, with the sale of standing timber, the price of meat per kilogram could be reduced by $25 \%$ (sold at US\$ $0.86 \mathrm{~kg}^{-1}$ ). In the case of roadside timber, this price reduction could be $33 \%$ (sold at US\$ $0.78 \mathrm{~kg}^{-1}$ ), and for timber delivered to the customer, meat per kilogram could reach $39 \%$ in price reduction (sold at US\$ $0.70 \mathrm{~kg}^{-1}$ ).

When considering a constant price of meat, price reductions of standing, roadside and delivered-to-customer timbers should be 56, 57 and $59 \%$, respectively, for the NPV to be close to 0 . In this sense, Dube et al. (2002) have found that variations of $\pm 20 \%$ of sale price of cattle significantly affected the sensitivity analysis, closely followed by price variations of wood for lumber and energy.

The system was found to be significantly tolerant to the increase of production costs in the three situations, with product prices remaining constant. The alternative of sale of standing timber was the most sensitive, being unfeasible when costs increased by more than $67.1 \%$. The sale of roadside timber tolerated an increase in production costs by $77.2 \%$, while timber delivered to the customer could have a cost increase of $85.2 \%$, before becoming unfeasible. However, Dube et al. (2002) found that establishment cost variations of $\pm 20 \%$ of the forest component significantly affected the economic indicators. These results corroborate the assertion by Souza et al. (2007) that adding value to forest products is very likely to increase the viability and safety of the agrosilvipastoral system.

Considering the constant prices and costs, and varying the quantities of the produced timber, meat and corn, it was found that for the standing timber sale, roadside sale of timber and sale of timber delivered to the customer, timber productions are 56.10, 57.30 and $58.60 \%$ higher, respectively, than the break-even-point (Table 5). For meat, the production for each alternative is $25.6,32.87$ and $38.7 \%$ higher than the break-even-point. The variation in corn production showed the lowest impact on the system feasibility. The standing timber alternative is $82.5 \%$ higher than the break-even-point. Even if corn production is zero, the two other alternatives still remain feasible.

Coelho Júnior et al. (2008) studied the economic viability of an agrosilvipastoral system in endangered Brazilian Cerrado, and came to similar conclusions, which is that investment in agrosilvipastoral systems is considered of low risk.

The effect of the discount rate on the NPV for the three alternatives studied is showed in Table 6. It can be seen that it increases with the decrease of the NPV, which becomes negative when the discount rate is $12 \%$, and all the alternatives become economically unfeasible. In this sense, Oliveira et al. (2000) found that discount rates higher than $11.45 \%$ turned unfeasible an agrosilvipastoral project system with eucalyptus, established in the Cerrado. Soares et al. (2003) stressed that this trend is expected, since high discount rates are an obstacle to long-term investments, due to the amount of time required for investment conversion, as is the case for forest-based investments.

Table 5. Break-even-point for the three alternatives: 1, sale of standing timber; 2 , sale of roadside timber; and 3, sale of timber delivered to the customer, by product ${ }^{(1)}$.

\begin{tabular}{lcccc}
\hline Agrossilvicultural product & Year & 1 & 2 & 3 \\
\hline Forest product & & & & \\
Firewood (st) - real value & 7 & 8.78 & 8.54 & 8.28 \\
Fencing stakes (unit) & 7 & 44 & 43 & 41 \\
Posts (unit) & 7 & 1 & 1 & 1 \\
Standing timber (m $\left.{ }^{3}\right)$ & 10 & 17.56 & - & - \\
Sawn timber $\left(\mathrm{m}^{3}\right)$ & 10 & - & 6.79 & 6.58 \\
Firewood $\left(\mathrm{m}^{3}\right)$ & 10 & - & 2.73 & 2.65 \\
Fencing stakes (unit) & 10 & - & 60 & 58 \\
Animal product & & & & \\
$\quad$ Meat production (kg) & $2-10$ & 227 & 205 & 187 \\
Crop production & & & & \\
$\quad$ Corn (kg) & 2 & 700 & - & - \\
\hline
\end{tabular}

${ }^{(1)}$ The break-even-point was calculated separately for each product category (forest, animal and crop products), maintaining the others constant. ${ }^{(2)}$ Source: Carvalho et al. (2002).

Table 6. Effect of variation in discount rates in the net present value for the three alternatives: 1 , sale of standing timber; 2 , sale of roadside timber; and 3, sale of timber delivered to the customer.

\begin{tabular}{lccc}
\hline $\begin{array}{l}\text { Discount rate } \\
(\%)\end{array}$ & $\begin{array}{c}\text { Alternative 1 } \\
\text { (US\$) }\end{array}$ & $\begin{array}{c}\text { Alternative 2 } \\
\text { (US\$) }\end{array}$ & $\begin{array}{c}\text { Alternative 3 } \\
\text { (US\$) }\end{array}$ \\
\hline 6 & 576.12 & 726.44 & 872.21 \\
8 & 272.41 & 409.43 & 518.21 \\
10 & 12.16 & 126.21 & 216.80 \\
12 & -211.97 & -116.73 & -41.56 \\
\hline
\end{tabular}




\section{Conclusions}

1. The three alternatives for timber revenue are economically viable at a $6 \%$ discount; however, adding value to forest products increases their attractiveness.

2. The viability of this system is highly dependent on silviculture and livestock.

3. The sensitivity of animal product decreases by adding value to forest products.

4. The system has high tolerance to increasing production costs and low sensibility to price variations, and the alternative which tolerates the highest increase in production costs is the delivery of timber to the customer.

5. Adding value to forest products leads to an increase in profitability and safety of the system.

\section{Acknowledgements}

To Prof. Carlos Pedro Boechat, Departamento de Engenharia Florestal, Universidade Federal de Viçosa, for lending the Weeler pentaprism equipment.

\section{References}

CARVALHO, M.M.; ALVIM, M.J.; XAVIER, D.F.; YAMAGUCHI, L.C.T. Estabelecimento de sistemas silvipastoris: ênfase em áreas montanhosas e solos de baixa fertilidade. Juiz de Fora: Embrapa Gado de Leite, 2002. 12p. (Embrapa Gado de Leite. Circular técnica, 68).

CASTRO, C.R.T. de; GARCIA, R.; CARVALHO, M.M.; COUTO, L. Produção forrageira de gramíneas cultivadas sob luminosidade reduzida. Revista Brasileira de Zootecnia, v.28, p.919-927, 1999.

CASTRO, C.R.T. de; PACIULLO, D.S.C.; GOMIDE, C.A. de M.; MULLER, M.; NASCIMENTO JUNIOR, E.R. do. Características agronômicas, massa de forragem e valor nutritivo da Brachiaria decumbens em sistema silvipastoril. Pesquisa Florestal Brasileira, v.60, p.19-25, 2009.

COELHO JÚNIOR, L.M.; RESENDE, J.L.P. de; OLIVEIRA, A.D. de; COIMBRA, L.A.B.; SOUZA, A.N. de. Análise de risco de um sistema agroflorestal sob situação de risco. Revista Cerne, v.14, p.368-378, 2008.

DEMAERSCHALK, J.P. Converting volume equations to compatible taper equations. Forest Science, v.18, p.241-245, 1972.
DUBE, F.; COUTO, L.; SILVA, M.L. da; LEITE, H.G.; GARCIA, R.; ARAUJO, G.A.A. A simulation model for evaluating technical and economic aspects of an industrial eucalyptus-based agroforestry system in Minas Gerais, Brazil. Agroforestry Systems, n.55, p.73-80, 2002.

FONTES, A.A.; SILVA, M.L. da; VALVERDE, S.R.; SOUZA, A.L. de. Análise da atividade florestal no Município de Viçosa, MG. Revista Árvore, v.27, p.517-525, 2003.

FRANCO, F.S. Sistemas agroflorestais: uma contribuição para a conservação dos recursos naturais na Zona da Mata de Minas Gerais. 2000. 148p. Tese (Doutorado) - Universidade Federal de Viçosa, Viçosa.

LEITE, H.G.; CAMPOS, J.C.C.; PAULA JUNIOR, G.G. Emprego de um modelo de programação dinâmica para conversão de troncos em multiprodutos da madeira. Revista Árvore, v.19, p.447-465, 1995.

MACEDO, R.L.G. Princípios básicos para o manejo sustentável de sistemas agroflorestais. Lavras: UFLA/FAEPE, 2000. 157p.

OLIVEIRA, A.D. de; SCOLFORO, J.R.S.; SILVEIRA, V. de P. Análise econômica de um sistema agro-silvo-pastoril com eucalipto implantado em região de Cerrado. Ciência Florestal, v.10, p.1-19, 2000.

PACIULLO, D.S.C.; CARVALHO, C.A.B. de; AROEIRA, L.J.M.; MORENZ, M.F.; LOPES, F.C.F; ROSSIELLO, R.O.P. Morfofisiologia e valor nutritivo do capim-braquiária sob sombreamento natural e a sol pleno. Pesquisa Agropecuária Brasileira, v.42, p.573-579, 2007.

PACIULLO, D.S.C.; LOPES, F.C.F.; MALAQUIAS JUNIOR, J.D.; VIANA FILHO, A.; RODRIGUEZ, N.M.; MORENZ, M.J.F.; AROEIRA, L.J.M. Características do pasto e desempenho de novilhas em sistema silvipastoril e pastagem de braquiária em monocultivo. Pesquisa Agropecuária Brasileira, v.44, p.1528-1535, 2009.

PAES LEME, T.M.; PIRES, M. de F.A.; VERNEQUE, R. da S.; ALVIM, M.J.; AROEIRA, L.J.M. Comportamento de vacas mestiças Holandês x Zebu, em pastagem de Brachiaria decumbens em sistema silvipastoril. Ciência e Agrotecnologia, v.29, p.668-675, 2005.

SOARES, T.S.; CARVALHO, R.M.M.A.; VALE, A.B. do. Avaliação econômica de um povoamento de Eucalyptus grandis destinado a multiprodutos. Revista Árvore, v.7, p.689-694, 2003.

SOUZA, A.N.; OLIVEIRA, A.D. de; SCOLFORO, J.R.S.; REZENDE, J.L.P.; MELLO, J.M. de. Viabilidade econômica de um sistema agroflorestal. Cerne, v.13, p.96-106, 2007.

XAVIER, D.F.; CARVALHO, M.M.; ALVIM, M.J.; BOTREL, M.A. Melhoramento da fertilidade do solo em pastagem de Brachiaria decumbens associada com leguminosas arbóreas. Pasturas Tropicales, v.25, p.23-26, 2003.

Received on April 8, 2010 and accepted on July 22, 2011 